\title{
MEMAKNAI MANAJEMEN BISNIS ISLAMI SEBAGAI KEHIDUPAN YANG MENGHIDUPI
}

\author{
Amelia Indah Kusdewanti ${ }^{11}$ \\ Rina Hendrawaty ${ }^{2)}$ \\ ${ }^{1)}$ Universitas Brawijaya, J1. MT. Haryono 165, Malang \\ ${ }^{2)}$ Universitas Wisnuwardhana, J1. Danau Sentani 99, Malang \\ Surel: amelia_indah15@yahoo.co.id \\ r1n4pasca@yahoo.com
}

\begin{abstract}
Abstrak. Memaknai Manajemen Bisnis Islami Sebagai Kehidupan yang Menghidupi. Penelitian ini bertujuan memaknai manajemen bisnis Islami yang dijalankan oleh penjual bubur sehingga menghasilkan bisnis yang bukan hanya sebagai kegiatan yang bersifat self interest akan tetapi bisnis sebagai kehidupan yang menghidupi, dan juga memberikan gambaran lingkungan bisnis yang holistik dengan mengintegrasikan unsur spiritual religi-sosial ke dalam bisnis. Penelitian ini menggunakan fenomenologi yang diekstensikan dengan konsep Tauhid Al-Faruqi. Temuan penelitian menunjukkan bahwa manajemen bisnis Islami mendasarkan kegiatannya pada ketaatan, istiqomah, keikhlasan yang disandarkan pada Allah SWT sehingga memunculkan manajemen bisnis Lillahi Ta'ala dengan Tauhid sebagai landasan utamanya, hal ini membuka jalan pembebasan ekonomi Islam yang masih terkurung dalam bayang-bayang ekonomi kapitalis.
\end{abstract}

Abstract. Interpreting Islamic Business Management as a Life Support. The purpose of this research is to show how Islamic management practiced who worked by porridge's seller so produce not only self interest business but also business as life support, and then giving description about holistic business environment with intergrating spiritual religi-social into business. This research uses phenomenology which extended with Al-Faruqi's Tauhid concept. The result of this research shows that Islamic management business put the basic of its activity to loyalty, istiqomah, sincere which based on Allah SWT so appearing Lillahi Ta'ala business management with Tauhid as main principle, this way will open Islamic economy liberating that still trapped in the shadow of capitalist economic.

Kata kunci: Manajemen Bisnis Islami, Fenomenologi, Tauhid

"The devil is not as

black as he is painted"

\section{(Dante Aleghieri)}

Seperti ungkapan Dante dalam metafora devil, bahwa bisnis juga penuh tipu daya, terlihat sangat putih sementara kebanyakan kulit aslinya adalah hitam seperti yang dilukiskan. Bisnis merupakan kehidupan bagi banyak orang. Bisnis menjadi sangat penting karena bisnis dapat mendukung kegiatan perekonomian yang saat ini sedang berkembang. Akan tetapi, kondisi perekonomian saat ini didukung dan dikuasai sepenuhnya oleh bisnis kaum kapitalis, bahkan Porter dan Kramer (2011) dan Mackay (2006) menyatakan bahwa bisnis memang seharusnya tidak perlu meninggalkan ke-kapitalisme-an mereka. Sombart (2001) dan Chiapello (2007) sebagai sebuah sistem bahwa pemilik segala modal dan hasilnya adalah pemilik modal sedangkan pekerja tidak mendapatkan apapun kecuali pekerjaannya. Hal ini yang sangat bertentangan dengan nilai-nilai keislaman sehingga perlu adanya perubahan dalam kemapanan pergerakan dan perkembangannya.

Saat ini bak belenggu indah yang memikat, pengelolaan bisnis

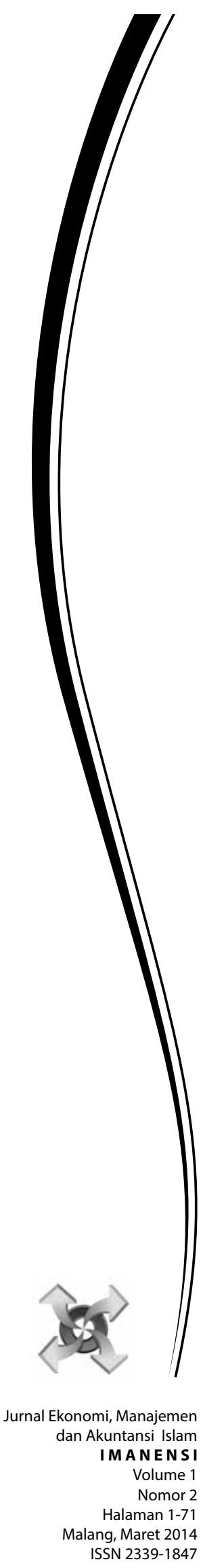


berubah menjadi sebuah tirani yang sarat akan nilai-nilai kepuasan pribadi berbasis materi yang merupakan manifestasi dari ekonomi kapitalis yang berkembang. Para pelaku bisnis mengambil sumber kehidupan orang-orang kecil. Pusat-pusat perbelanjaan di tengah kota menggeser tempat mbahmbah penjual dawet, cilok, nasi pecel, nasi jagung, penjual weci, penjual daging, dan penjual lupis. Inilah belenggu yang sangat kelihatan indah jika kita berada bersama dengan orang-orang yang menikmati belenggu itu.

Perbincangan yang pernah dilakukan oleh penulis terhadap beberapa orang pelaku bisnis terkait dengan alasan menjalankan bisnis, yaitu hampir serempak memberikan jawaban bahwa tujuan melakukan bisnis adalah untuk mendapatkan untung yang tinggi.

"Lha kan yo enak to, kalau bisnis untung di pek dewe, lha lek kerjo karo uwong kan gak iso untung tinggi, gajine cilik pisan"

(Lha kan ya enak kalau bisnis untung di miliki sendiri, kalau kerja pada orang lain kan tidak bisa mendapatkan keuntungan yang tinggi, gajinya juga kecil)

Hal ini merupakan suatu fenomena yang sangat perlu ditelaah bahwasanya jika mental berbisnis dengan memiliki tujuan akhir untuk materi, maka jangan heran jika manajemen adalah sebuah cara untuk mencapai tujuan tersebut. Mental bisnis inilah yang menjadi bibit-bibit terciptanya ekonomi kapitalis yang merajai ekonomi kita saat ini. Pendekatan kesejahteraan ekonomi mempertimbangkan konsumsi dari barang-barang dan jasa sebagai dasar untuk kehidupan yang lebih baik, akan tetapi seperti yang terlihat bahwa hal itu menolak spiritual manusia, kebutuhan moral dan perkembangan kapasitas mental dalam proses perkembangannya (Zangoeinezhad dan Moshabaki 2011).

Muslim saat ini sedang terdominasi oleh konsep manajerial yang materialistik, tidak bisa lepas dari kerangka fungsional yang dibangun atas dasar dan akhir pada materi. Atas ketidaksadaran dan keterjebakan inilah yang menyebaban runtuhnya semangat dan upaya untuk menciptakan konsep baru tentang manajerial dengan prinsip-prinsip Islam karena dianggap sudah bisa dipraktekan jadi tidak perlu dirubah lagi. Salah satu alasan atas ketidaksadaran ini salah satunya menurut Mohiudin (2012) adalah kurangnya penelitian dan kelalaian dari golden history tentang Islam, sehingga kaum Muslim hari demi hari didominasi oleh konsep manajerial yang sekuler dan materialistik.

Pergerakan dari bisnis-bisnis UKM yang saat ini sedang berkembang dan berjuang untuk kelangsungan hidupnya memerlukan perhatian lebih, karena saat ini perhatian tertuju pada bisnis-bisnis besar seperti MNC (Multi National Company). Lalu jika bisnis kecil yang menjadi tumpuan masyarakat bawah untuk kelangsungan hidupnya sendiri saja masih berjuang, bagaimana cara mereka "menghidupi" yang lainnya?

Kehidupan yang menghidupi adalah ketika bisnis-bisnis mampu bukan saja menghidupi dengan materi saja akan tetapi menghidupi mental dan spiritual relijius sehingga mampu menciptakan nilai-nilai keislaman yang mendorong terciptanya lingkungan ekonomi Islam yang sehat secara batin-reliji manusia yang terlibat dalam kegiatan tersebut. Dalam hal ini sebagai penegak dan fondasi utama ekonomi Islam, maka karakteristik manajemen bisnis Islami merupakan basis yang sangat penting dalam memproduksi bisnis Islami dan bukan "mereproduksi" bisnis konvensional "berbaju" Islam seperti kebingungan yang dialami oleh Alani et al. (2013) dan Noruzi (2011), maka dari itu diperlukan tata kelola (manajemen) yang berbeda dengan bisnis konvensional.

Bisnis Islami adalah sebagai pendobrak utama belenggu-belenggu liberal yang terus bereproduksi dimana-mana untuk menciptakan kemaslahatan umat, bukan saja memiliki tujuan akhir yang baik (kemaslahatan umat), akan tetapi diawali dan berjalan dengan proses yang baik yaitu sesuai dengan nilai-nilai dan etika Islam. Sehingga tidak ada lagi jeritan-jeritan yang terpotret seperti gambaran Marx bahwa terjadi eksploitasi dalam kegiatan bisnis (terutama pekerja). Karena potret tersebut bukanlah gambaran bisnis yang dihasilkan dari manajemen bisnis Islami.

Lingkungan manajemen bisnis Islami meliputi atmosfer spiritualitas relijius dimana ketuhanan adalah pusat dari semua tujuan kegiatan, kesadaran ini harus muncul disetiap kegiatan seorang Muslim (Al Faruqi 1998:1) dalam lingkungan bisnis yang dihasilkan adalah lingkungan the unity of $G O D$, there is no god but GOD. Kesadaran 
manusia dalam memahami siapa dirinya akan membawa hubungan pada saudaranya (sesama Muslim) dan membawa prinsip amanah, sidiq sebagai khalifatullah fill ardh.

Penelitian mengenai manajemen bisnis Islami, sebenarnya sudah dilakukan oleh beberapa peneliti seperti Alani et al. (2013), Fontaine (2008), Noruzi (2011), Branine dan Pollard (2010). Alani (2013), meneliti tentang manajemen keuangan entitas bisnis syariah walaupun tidak menjabarkan secara jelas tentang bagaimana bisnis Islami itu berbeda antara satu dengan lainnya serta bagaimana asumsi dan prinsip dasar yang melandasi berdirinya suatu entitas bisnis syariah. Lebih lanjut, Fontaine (2008) sendiri melakukan penelitian pada mahasiswa, yang diklaim olehnya sebagai sebuah model yang dinamakannya $\mathrm{A} 6 \mathrm{H}$, walaupun sebenarnya kami menganggap bahwa model tersebut lebih condong pada kerangka konseptual. Fontaine (2008) membangun asumsi dasar A6H, yaitu AL Qur'an dan Hadist, sebagai dasar, akan tetapi Fontaine (2008) tidak menurunkan secara pasti langkah-langkah dari konsep yang sudah dibuat.

Branine dan Pollard (2012) membuat gambaran bagaimanakah HRM (human resource management) entitas bisnis syariah, membawa asumsi-asumsi tentang manusia yang dijelaskan dalam Al-Qur'an. Sebenarnya penelitian mengenai manajemen bisnis Islami yanga ada di Indonesia dilakukan oleh Choudury dan Harahap (2009) dengan berlandaskan pada Tauhid dalam melakukan bisnis, dijelaskan disini mengenai bagaimana prinsip dasar yang harus dibawa oleh manusia karena manusia adalah khalifatullah fil ardh. Mereka menjelaskan bagaimana sebuah bisnis memberikan kontribusi pada masyarakat kecil di sekitarnya, akan tetapi dalam penelitiannya adanya hambatan dari regulator yang tidak mendukung.

Noruzi (2011) juga memberikan gambaran mengenai entrepreneurship dalam kerangka sistem konvensional dan Islam. Akan tetapi apa yang dilakukan oleh Noruzi (2011) ini tidak memberikan gambaran secara lengkap. Karena yang dilakukan oleh Noruzi (2011) hanya memberikan bagaimana entrepreneurship konvensional dan bagaimana entrepreneurship Islami. Noruzi hanya berputar-putar pada persoalan yang sudah "jadi" artinya asumsi dan landasannya tidak di otak-atik.

Alasan penelitian ini mengangkat bisnis penjual bubur adalah untuk mengang- kat nilai-nilai bisnis Islami yang tercermin pada praktek bisnis lokal sebagai UKM yang merupakan pendukung dari kegiatan ekonomi kerakyatan berbasis syariah dan Tauhid di dalam kegiatan berbisnis. Fokus penelitian ini terbatas pada isu-isu manajemen mengenai kepemimpinan, komunikasi, motivasi dan lingkungan bisnis Islami. Struktur penulisan penelitian ini terdiri dari lima bagian, pertama pendahuluan yang berisi latar belakang penulisan penelitian ini, kedua telaah kritis terhadap manajemen bisnis konvensional, ketiga prinsip manajemen bisnis Islami, keempat hasil dan pembahasan, dan yang kelima kesimpulan. Penelitian ini bertujuan untuk memaknai manajemen bisnis Islami yang dilakukan sehingga menghasilkan bisnis yang bukan hanya sebagai kegiatan yang bersifat self interest akan tetapi bisnis sebagai kehidupan yang menghidupi dalam koridor-koridor keislaman untuk mendukung tercapainya keseimbangan antara unsur material-spiritual religi-sosial dan memberikan gambaran tentang lingkungan bisnis yang holistik dengan mengintegrasikan unsur spiritual religi-sosial ke dalam bisnis sebagai fondasi ekonomi Islam dan menggagas skema manajeman bisnis yang menghidupi.

\section{Telaah Kritis atas Manajemen Bisnis Kon- vensional}

Manajemen bisnis merupakan upaya untuk menjalankan bisnis dan menghasilkan bisnis yang diinginkan. Selama ini manajemen bisnis dibutuhkan untuk mencapai tujuan bisnis yaitu profit. Dalam manajemen bisnis yang diadopsi dari barat mengandung nilai-nilai liberalism yang dominan dan materialistis serta tidak begitu menyinggung masalah etika. Etika mempunyai dua dimensi utama, yaitu pertama etika kepada Tuhan, sang pencipta. Seorang Muslim harus beriman kepada Tuhan dan beribadah kepadaNya. Yang Kedua adalah etika kepada sesama manusia (Dewi dan Dhewanto 2012). Dalam manajemen konvensional manajer mengukur kesuksesan hanya dengan akumulasi materialistis yang didapatnya, sehingga sering melupakan jalan kebenaran untuk memperolehnya (Khan et al. 2010). Dalam etika bisnis secara umum terdapat fakta bahwa dalam penggunaan etika-etika bisnis yang terjadi saat ini memang merujuk pada standar-standar etika dari dunia barat dengan bersikap taqlid, menerima semua begitu saja tanpa mengetahui landasan utama 
prinsip-prinsip etika tersebut. Seharusnya jika ingin menerapkan etika-etika tersebut harus mengetahui secara keseluruhan bukan parsial, keseluruhan yang dimaksud disini adalah bahwa asumsi-asumsi yang mendasari prinsip-prinsip etika tersebut apa sudah dibangun dengan fondasi yang sesuai dengan Islam, Rizk (2008) menyatakan:

\section{"Most studies on business ethics in general, and the work ethic in particular, have been based on the experiences of Western nations. The focus has always been on the Protestant work ethic (PWE) as ad- vanced by Max Weber, who proph- esied a relationship between Prot- estantism and capitalism"}

Karena tujuan utama dalam bisnis adalah keuntungan yang sebesar-besarnya maka manajemen yang digunakan sebagai alat pun menjadi pegangan untuk merealisasikan tujuan bisnis tersebut dengan fungsi-fungsinya yang telah digagas oleh Fayol yaitu planing, organizing, actuating dan controlling. Akan tetapi menurut Mas'ud (2008:42), manajemen yang digagas oleh barat tidak bisa hanya dimaknai sebagai sekedar menjalankan fungsi-fungsi tersebut, akan tetapi manajemen sebagai wacana (panopic discourse) yaitu upaya memperbanyak kekuasaan dan mempertahankan ketertiban normatif dengan menggunakan informasi, teknologi, sistem, aturan-aturan dan sebagainya yang dilakukan oleh sekelompok orang. Jika dalam konteks ini maka bisa dikatakan dalam fungsi manajemen sendiri terjadi asimetry of power.

Manajemen bisnis konvensional atau modern dianggap mengabaikan aspek sosial dan psikologi karyawannya lebih lanjut manajemen konvensional menekankan pentingnya rasionalitas ekonomi (Mas'ud 2008:42). Pada sudut pandang kritis manajemen sendiri dianggap sebagai pengetahuan yang diproduksi untuk menguasai, karena tujuan dari manajemen mengendalikan perilaku manusia (Mas'ud 2008:67). Lebih lanjut, spiritualitas sendiri sebagai paradigma baru dalam dunia bisnis ternyata juga digunakan untuk mengejar keuntungan yang sebesar-besarnya.

Apa yang membedakan antara bisnis konvensional dengan bisnis Islami seperti yang telah disinggung di atas? Dalam Islam, kegiatan manusia dalam berbisnis tidak dapat dipisahkan dengan hakekat manusia da tujuan hidupnya (Mas'ud 2008:182). Lebih lanjut, pemecahan-pemecahan yang terjadi dalam manajemen konvensional merupakan manifestasi yang terjadi dalam mencapai tujuan self saja (Alvesson dan Willmot 2007:21). Manusia diciptakan dengan tujuan tertentu (Al Faruqi 1998:4). Secara epistemologis sumber pengetahuan bukan hanya dari akal (rasio) tapi juga wahyu dari Allah SWT (Mas'ud 2008:182).

Menurut Mas'ud, bisnis Islami merupakan semua kegiatan yang menghasilkan produk dengan tujuan mencari keuntungan yang halal. Akan tetapi apa yang dimaksud Mas'ud mencari keuntungan yang halal merupakan sebuah konsep yang belum tepat menurut kami, karena kembali lagi pada tujuan penciptaan manusia bahwa manusia diciptakan untuk beribadah kepada Allah (Al Faruqi 1998), maqashid syariah adalah untuk kesejahteraan umat bukan untuk self. Mas'ud (2008) tidak mengintegrasikan antara tujuan penciptaan manusia dengan kegiatan bisnis yang ada walaupun sudah menyebutkan nature bisnis Islami yang berbeda dengan konvensional.

Boleh dibilang pioneer di bidang manajemen adalah Taylor dan Fayol, yang membedakan keduanya adalah bahwa Taylor ada di level teknis sedangkan Fayol ada di level administratif. Menurut Fayol, manajemen di dalamnya termasuk semua aktivitas yang berkaitan dengan memproduksi, mendistribusi dan menjual sebuah produk (Wren dan Bedeian 2009:213).

"What we are all looking for, however, is the readymade, competent man; the man whom some one else has trained. It is only when we fully realize that our duty, as well as our opportunity, lies in systematically cooperating to train and to make this competent man, instead of in hunting for a man whom some one else has trained, that we shall be on the road to national efficiency."

Inilah yang diungkapkan oleh Taylor dalam scientific management (1911), bahwa training yang dilakukan dalam manajemen adalah untuk mendapatkan karyawan yang kompeten dalam bidangnya sesuai dengan tujuan perusahaan. Hal ini berbeda dengan manajemen di dalam Islam.

"HRM Islam since the education and training system of the Islam 
emphasizes on the relation between an individual and the creator, faith and believe in God as well as relation with oneself and self-refinement. In other words, efflorescence of human capabilities and potentials is not one-dimensional, but it covers all aspects and dimensions including human's social, individual, physical, spiritual and material needs." (Zangoeinezhad dan Moshabaki 2011)

Seperti yang diungkapkan oleh Zangoeinezhad dan Moshabaki (2011) bahwa pendidikan dan pelatihan HRM (Human Resource Management) dalam Islam menekankan pada hubungan antara seorang individu dan penciptanya, iman dan percaya pada Tuhan sebagaimana hubungan untuk diri sendiri dan perbaikan pada diri sendiri. Pengembangan sumberdaya karyawan tidak hanya berdimensi pada material untuk tujuan efisiensi saja akan tetapi didalamnya untuk kebutuhan material, spiritual, sosial, individual dan fisik. Ini merupakan bantahan terhadap apa yang diungkapkan oleh Taylor(1911) yang menganggap manusia adalah mesin dan terlebih lagi dapat dibentuk sesuai kebutuhan pemilik usaha/ atasan. Kebebasan dalam menggerakkan karyawan dikorbankan dan terkekang demi terciptanya efisiensi.

Bagi perusahaan menurut Taylor, kebingungan terjadi dalam konsep kemakmuran yang dicetuskannya dimana kemakmuran pemilik adalah penting, tapi harus sejalan dengan kemakmuran karyawan, akan tetapi kemakmuran karyawan disini lebih ke sisi produktifitasnya, bukan sisi gaji yang dibayarkan oleh pemilik, dan disebutkan pula ada kelas, pembagian kelas sendiri seperti Mas'ud (2008) merupakan sebuah sistem yang mengarah pada perbudakan.

"The principal object of management should be to secure the maximum prosperity for the employer, coupled with the maximum prosperity for each employee. The words "maximum prosperity" are used, in their broad sense, to mean not only large dividends for the company or owner, but the development of every branch of the business to its highest state of excellence, so that the prosperity may be permanent. In the same way maximum pros- perity for each employee means not only higher wages than are usually received by men of his class, but, of more importance still, it also means the development of each man to his state of maximum efficiency"

Ada hal-hal yang mempengaruhi manajemen seperti dalam penelitian kami, kenapa manajemen yang digagas oleh Taylor berbeda sama sekali dengan temuan kami, karena dalam temuan kami bahwa manajemen yang diterapkan oleh Abah merupakan manajemen yang dipengaruhi oleh belief system yang dimilikinya. Sistem ini dipengaruhi oleh ketauhidan yang Abah sebut sebagai Lillahi Ta'ala, ini menjadi bantahan atas pernyataan Taylor (1911/2004) bahwa manajemen miliknya bisa diterapkan pada berbagai kondisi.

"To prove that the best management is a true science, resting upon clearly defined laws, rules, and principles, as a foundation. And further to show that the fundamental principles of scientific management are applicable to all kinds of human activities, from our simplest individual acts to the work of our great corporations, which call for the most elaborate cooperation."

Lingkungan bisnis Islami tidak bisa disamakan dengan lingkungan bisnis yang berbasis kebarat-baratan tanpa memperhatikan adanya sebuah kepercayaan didalam sanubari.

\section{Prinsip Manajemen Islami}

Dalam Islam, manajemen berfungsi sebagai proses koordinasi aktivitas yang mengacu pada prinsip-prinsip yang diturunkan langsung atau bersumber langsung dari Al-Qur'an dan Hadits (Branine dan Pollard 2010). Karena itu manajemen melampaui fisik, dalam artian tidak mengabaikan aspek-aspek spiritual yang ada dalam Islam karena itu lebih lanjut menurut Branine dan Pollard (2010) manajemen merupakan sebuah fungsi moral, spiritual dan fisik yang tidak hanya digerakkan oleh tujuan-tujuan duniawi akan tetapi juga digerakkan oleh rewards akhirat. Untuk menjadi sukses menurut (Khan et al. 2010) seorang manajer harus selalu menaati perintah Allah SWT dan pesan dari Rasulallah SAW, dalam artian kesuksesan yang disebutkan adalah bukan 
kesuksesan secara duniawi saja akan tetapi juga untuk kesuksesan akhirat.

Jika orang berpegang teguh pada Tauhid, maka rivalitas dan persaingan tidak akan terjadi karena yang melekat adalah saling respek satu sama lain, silaturrahmi, saling tolong-menolong (Choudury dan Harahap 2009, Fontaine et al. 2012). Menurut Ather et al. (2011) bahwa sangat jelas sekali bukan hanya produk saja yang harus halal, akan tetapi berjalan mulai tujuan sampai menuju realisasi akhir dari manajemen bisnis yang dilaksanakan juga harus halal, dalam artian tidak melanggar norma-norma dan etika berbisnis dalam sudut pandang dan ruang lingkup Islam.

"Islamic management, it is the process of achieving the Islamically approved (Halal) objectives of an organization following Islamically approved (Halal) procedures, methods, tools and techniques, through the group efforts and co-operations of members of the organization under the boundaries and frameworks of the rules, principles and regulations of Islam with a view to having the blessings and satisfaction of Allah Subhanahu Wa Tawala (SWTA) [2], The Almighty and Most Merciful (Ather, 2007). (Ather et al. 2011)

Hal inilah yang membedakan antara bisnis Islam dan bisnis konvensional, karena nature dari lingkungan bisnis Islami sendiri berangkat dari keyakinan bahwa bukan hanya materi dunia sebagai tujuan akhir, akan tetapi akhirat sebagai tujuan akhir, dan dunia tidak bisa dipisahkan dengan akhirat karena dunialah yang akan menentukan bagaimana akhirat nantinya (Al Attas 2001:1).

Prinsip manajemen Islami harus membawa nilai-nilai yang berlandaskan pada nilai-nilai Islam yang membentuk value system dan pola-pola Islam yang mempunyai karakter yang berbeda dengan manajemen bisnis konvensional. Keadilan sosial merupakan batu fondasi dari Islamic value system, tidak bisa diterima jika pola-pola Islam di dalam manajemen tidak membangun keadilan (Abbasi et al. 2010). Selain itu, dalam manajemen bisnis Islam, harus membebaskan dari segala bentuk ketidakadilan yang ada, penjajahan dan meluruskan kesalahankesalahan yang ada (Rice 1999, Abbasi et al. 2010, Khan et al. 2010).

Harus diingat bahwa apapun yang ada di muka bumi adalah milik Allah semata, dan manusia adalah Khalifah di muka bumi (Khan et al. 2010). Untuk sama-sama menuju kebaikan maka manusia diperintahkan untuk saling tolong menolong dalam kebaikan. Manusia diciptakan dengan tujuan tertentu.

"Since everything was created for a purpose - the totality of being no less so - the realization of that purpose must be possible in space and time. Otherwise there is no escape from cynicism. Creation itself, the processes of space and time, would losse their meaning and significance. Without this possibility, taklif (charge, moral obligation, responsibility), falls to the ground; and with its fall, either God's purposiveness or His might is destroyed." (Khan et al. 2010)

Dalam semua perusahaan, manajemen mambuat subordinatnya mengerti dan percaya bahwa mereka bertanggung jawab untuk pekerjaan mereka bukan saja kepada organisasi tempat mereka bekerja saja, akan tetapi juga kepada Allah, dan Islam memandang apa yang mereka kerjakan merupakan sebuah bentuk ibadah kepada Allah (Khan et al. 2010). Islam mencakup keimanan, ini mengatur setiap aspek dalam kehidupan, sosial dan pribadi, politik dan ekonomi, dan relevan untuk aktivitas bisnis. Dengan kata lain tidak ada pemisahan antara aspek dunia dan aspek relijius dalam hidup (Tayeb 1997), seperti yang telah disinggung oleh Al Attas (2001) bahwa aspek dunia dan akherat tidak bisa dipisahkan.

Dalam perspektif Islam, bagaimana membangun kesuksesan harus berdasarkan pada Al-Qur'an dan Hadits dimana bisnis memiliki sebuah etika dan moral (Dewi dan Dhewanto 2012). Sebagai subjek dari moral action, manusia karena itu mampu merubah dirinya sendiri, rekannya ataupun masyarakat, alam dan lingkungannya, sehingga untuk mengaktualisasikan pola Ilahi (the divine pattern), firman ke dalam dirinya sebaik kepada mereka. (Al Faruqi 1998:13). 


\section{Fondasi Manajemen Bisnis Islami}

\section{Leadership}

Kepemimpinan adalah hal utama di dalam manajemen, seperti yang dicontohkan oleh Nabi Muhammad SAW (Abbasi et al. 2010). Seorang pemimpin akan menjadi penentu bagaimana perusahaan meraih tujuannya. Seorang pemimpin Muslim harus melindungi komunitasnya melawan tirani dan penjajahan, mendukung kesadaran berketuhanan dan menciptakan keadilan sosial (Khan et al. 2010). Pemimpin mampu menggerakkan setiap pekerjanya untuk selalu ingat kepada Allah dan bahwa setiap pekerjaan yang dilakukan oleh pekerjanya merupakan ibadah dan harus selalu menanamkan rasa bahwa Allah selalu melihat setiap apa yang dikerjakan dalam bisnis. Jadi pemimpin tidak hanya menentukan strategi saja dalam mencapai tujuan perusahaan, akan tetapi kedekatan dengan karyawan harus tetap dijaga. Menggerakkan jiwa spiritual pekerjanya inilah pemimpin tidak hanya menghidupi secara materi saja akan tetapi menghidupi secara spiritual.

Untuk menghidupi secara spiritual, pemimpin harus mengikuti apa yang telah diinstruksikan oleh Al Qur'an dan Al Hadits, hal penting yang harus dipegang teguh oleh seorang pemimpin adalah kerendahan hati dan tanggung jawab (Abbasi et al. 2010), tanpa kerendahan hati maka tidak akan bisa seorang pemimpin mendekati karyawannya, tidak akan bisa mengambil hati karyawannya.

Pada level mikro, dalam hal ini UKMUKM, bisnisman Muslim yang baik harus dituntun oleh kesadaran mereka sendiri dan dengan instruksi dari Allah yang sudah tertulis dalam Al Qur'an, untuk melakukan hal baik terhadap orang lain. Dia harus membayar gaji yang sesuai, memberikan harga yang pantas, tidak melebih-lebihkan dan mengendalikan turunnya dalam hal ini profit, serta peduli terhadap lingkungan. Sadar bahwa Allah selalu terlibat dalam kegiatannya (Tayeb 1997).

Seorang pemimpin dalam bisnis harus memahami bagaimana karyawannya, bagaimana memaksimalkan kemampuan karyawannya dan tidak boleh memperlakukan karyawannya dengan tindakan yang tidak adil, dan dalam tekanan. Seorang pemimpin harus memperhatikan dalam memberikan pelatihan dan pendidikan kepada karyawannya sebagaimana yang disebutkan oleh (Zangoinezhad dan Moshabaki 2011).
"Since the education and training system of the Islam emphasizes on the relation between an individual and the creator, faith and believe in God as well as relation with oneself and self-refinement. In other words, efflorescence of human capabilities and potentials is not one-dimensional, but it covers all aspects and dimensions including human's social, individual, physical, spiritual and material needs."

\section{Atmosfer Bisnis Islami}

Dalam lingkungan bisnis islam terbentuk sistem nilai-nilai Islam didalamnya (Abbasi et al. 2010), national culture sangat mempengaruhi organisasi dan kerja, karena didalamnya terdapat nilai-nilai, attitude, dan behavior yang terbawa pada tempat kerja karyawan, berbagai kebijakan termasuk politik ekonomi dan juga tugas-tugas yang diberikan manajer sangat berpengaruh dalam organisasi, termasuk di dalamnya adalah agama (Tayeb 1997), lebih lanjut dijelaskan bahwa budaya merupakan sebuah fenomena sosial dimana didalamnya ada interaksi antara orang-orang (Tayeb 1997), tempat kerja adalah tempat untuk manifestasi dari nilainilai budaya Islami karena didalamnya ada interaksi antar karyawan dan pemimpinnya sehingga menciptakan atmosfer Islami.

"Religions in many countries, with either secular or religious constitutions, have a certain degree of influence on the cultural characteristics of their people and their institutions. This influence is far more extensive and inclusive in the countries that follow a model based on religious ideals." (Khan et al. 2010)

Seorang pemimpin disini berperan penting tentang bagaimana bersama-sama menggerakkan budaya Islami dalam perusahaan untuk membentengi diri dari kondisi budaya nasional yang tidak sesuai dari budaya Islami.

\section{Motivasi}

Dalam kegiatan manajemen sebenarnya penting juga untuk memotivasi orangorang yang secara umum terlibat dalam pengambilan keputusan. Etika dalam kegiatan manajemen memberikan kepuasan, keterlibatan, kebersamaan dan inovasi tersendiri dalam manajemen (Abbasi et al. 2010). 
Motivasi dalam manajemen konvensional diturunkan dari teori motivasi Maslow (Ather et al. 2011). Yang menjadi pertanyaan apakah motivasi ini sesuai dengan motivasi dalam Islam? Ketika menggunakan sebuah teori motivasi sekalipun, perlu sekiranya melihat lebih dalam akar dari teori ini, karena Islam menggunakan kode etik dan motivasi yang dilandasi oleh nilai-nilai relijius dan Tauhid, bukan hanya didasarkan atas rasa humanis yang melekat dalam sesama manusia, mengingat bahwa sudut pandang antara dunia barat dan Islam sangatlah berbeda, tidak ada pemisahan dunia dan akhirat dalam Islam, akhiratlah yang menjadikan motivasi dalam bisnis Islam. Perbedaan motivasi ini disoroti dengan jelas oleh Ather et al. (2011) bahwa Islam adalah code of life yang sangat lengkap dan berasal dari Al-Qur'an, maka motivasi pada manajemen Islam menempati peranan yang sangat signifikan dalam organisasi Islam, sehingga pedoman tentang motivasipun juga berbeda dengan manajemen konvensional. Tentunya teori-teori dan prinsip motivasi pada manajemen konvensional dan Islam tidaklah sama.

Ather et al. (2011) menyebutkan Choudury mengindikasikan bahwa tatanan hierarki Maslow tidak berlaku dalam manajemen dalam perspektif Islam. Struktur aktualisasi diri dalam Islam tidak sesederhana membalik dari struktur-struktur Maslownian. Tentu saja secara struktur sangat berbeda, evolusi sosial terkait dengan aktualisasi diri yang secara primordial terbentuk.

Lebih lanjut mengenai motivasi di dalam Islam, motivasi tidak terbatas dalam uang saja, seperti yang disebutkan dalam manajemen konvensional, bahwa jika dalam kontrak kerja yang diberikan pada karyawan yang amat penting adalah persoalan gaji. Uang menjadi motivasi yang sangat penting bagi manajemen konvensional karena menganggap bahwa uang adalah tujuan akhir seseorang. Seseorang akan melakukan apapun untuk mendapatkan uang. Akan tetapi, bentuk-bentuk motivasi sendiri menurut Abbasi et al. (2010) dan Ather et al. (2011) melebihi apa yang disebutkan manajemen konvensional yaitu uang. Jika uang yang menjadi motivasi, maka seolah-olah perusahaan tidak peduli dalam hal bagaimana kesejahteraan karyawannya itu, karena bagi perusahaan yang penting adalah adanya efisiensi.

Motivasi spiritual sangatlah penting dalam hal ini karena sudut pandang yang berbeda antara manajemen konvensional dan Islam, bahwa dalam Islam sendiri bukan materi sebagai tujuan akhir sebuah usaha akan tetapi bagaimana materi di dunia ini hanya sebagai jembatan untuk mendapatkan ketentraman akhirat, seperti yang tertuang dalam tulisan Ather et al. (2011) berikut ini.

\begin{abstract}
"Spiritual motivational drives and forces are the expectations for obtaining blessings of Allah SWT that will pave the way to permanent happiness (i.e. The Heaven) and efforts to save oneself from His (Allah's) curses that lead to permanent sorrows (i.e. The Hell). All activities of a Muslim are the resultant effects of his belief (Iman), i.e. his level and state of beliefs in "Oneness" and supremacy of the creator Allah SWTA, His Angels, His Devine Revelation (The Holly Quran), His Prophets, after world (Akhirah) that fortunes and calamities of Lord comes from Allah SWTAand the day of final judgement and revival of all human beings (Qiamatt)." (Ather et al. 2011)
\end{abstract}

Hal inilah yang tidak diungkapkan dalam motivasi pada manajemen konvensional, dimana yang ada dalam kegiatan manajemen Islam adalah akhirat. Motivasi akhirat yang harus ditanamkan di dalam setiap kegiatan seorang Muslim untuk mengingatkan bahwa dirinya suatu saat nanti tidaklah hidup di dunia selamanya, motivasi dalam berkerja harus diarahkan pada semua bahwa dalam kegiatan adalah dilakukan untuk memperoleh ridho dari Allah SWT.

\section{Komunikasi}

Komunikasi yang baik merupakan hal yang utama dalam manajemen bisnis, komunikasi akan membangun keparcayaan satu sama lain dan juga penting untuk pengambilan keputusan dalam bisnis (Dewi dan Dhewanto 2012, Abbasi et al. 2010, Fontaine 2012). Membangun media komunikasi antara manajer dan karyawan bisa melalui shura hal ini ditekankan oleh Abbasi et al. (2010), Fontaine $(2008,2012)$. Abbasi et al. (2010) menekankan akan pentingnya melaksanakan shura karena menjadi hal yang penting dalam manajemen untuk membentuk suatu komunikasi yang baik. Nasihat sendiri lebih dari sekedar saling menas- 
ehati dalam hal kebaikan menurut Fontaine (2008). Lebih dari itu, Fontaine juga menekankan pentingnya saling membantu satu sama lain dalam berbagai jalan. Hal ini mengimplikasikan cinta pada sesama, sebagai bentuk saling tolong-menolong antar manusia.

Akan tetapi menurut Fontaine et al. (2012), shura saja belum dirasa cukup untuk melakukan komunikasi dalam praktek manajemen yang ada, hal lain yang perlu diperhatikan adalah nasihat, yaitu kebaikan antar sesama. Dua hal tersebut merupakan pusat dari pengambilan keputusan yang utama dalam Islam. Lebih lanjut Fontaine menyebutkan bahwa nasihat dan shura ini sangatlah penting dalam pengambilan keputusan, shura ini dijelaskan dalam Al Qur'an:

"Maka disebabkan rahmat dari Allah-lah kamu berlaku lemah lembut terhadap mereka. Sekiranya kamu bersikap keras lagi berhati kasar, tentulah mereka menjauhkan diri dari sekelilingmu. Karena itu ma'afkanlah mereka, mohonkanlah ampun bagi mereka, dan bermusyawarahlah dengan mereka dalam urusan itu. Kemudian apabila kamu telah membulatkan tekad, maka bertawakkallah kepada Allah. Sesungguhnya Allah menyukai orang-orang yang bertawakkal kepada-Nya." (QS. Ali Imran: 159)

Dalam ayat diatas menurut tafsir Maudu'i disebutkan bahwa bagaimana seorang pemimpin dalam melakukan bermusyawarah haruslah mempunyai sikap lemah lembut, yang kedua memberi maaf dan membuka lembaran baru karena mungkin saja dalam bermusyawarah terjadi perbedaan pendapat atau keluar kata-kata yang menyinggung pihak lain. Dalam bermusyawarah analisis yang tajam saja tidak cukup, haruslah ada yang lainnya, maka hubungan dengan Allah pun harus harmonis.

\section{METODE}

Penelitian ini menggunakan fenomenologi, fenomenologi sendiri, yaitu memaknai/ menganalisa kesadaran individu (Burrel dan Morgan 1979:241). Menurut Kuswarno (2009:1) fenomenologi mempelajari fenomena yang nampak di depan kita dan bagaimana penampakannya. Fenomenologi ini dikembangkan oleh Husserl, dia menganggap bahwa science dicirikan dari kesadaran dan menangkap makna yang ada dalam diri sehingga membentuk fenomena.

Unsur-unsur dalam metode penelitian ini adalah noema yang merupakan dasar pikiran dan roh manusia, sesuatu yang diterima panca indera manusia sedangkan noesis adalah sisi ideal obyek dalam pikiran (Kuswarno 2009:43), epoche yaitu menyampingkan penelitian bias dan pertimbangan awal yang kita miliki terhadap suatu obyek. Reduksi fenomenologi (eidetic reduction) merupakan cara melihat dan mendengar suatu fenomena dengan kesadaran hatihati (Kuswarno 2009:50).

Akan tetapi dalam fenomenologi ini, menurut kami masih terjebak dalam aspek material, maka perlu adanya internalisasi nilai-nilai Tauhid didalamnya. Yang dimaksud material disini adalah terjebak dalam kerangka diri dimana kesadaran subyektif yang ada dalam diri seseorang hanya dipengaruhi oleh dunia dan pengalaman saja, kesadaran ini tidak sesuai dengan Islam, karena kesadaran terdalam manusia adalah kesadaran Tauhid, hal ini merujuk pada AlA'raf 172:

"Dan (ingatlah), ketika Tuhanmu mengeluarkan keturunan anakanak Adam dari sulbi mereka dan Allah mengambil kesaksian terhadap jiwa mereka (seraya berfirman): "Bukankah Aku ini Tuhanmu?" Mereka menjawab: "Betul (Engkau Tuban kami), kami menjadi saksi". (Kami lakukan yang demikian itu) agar di hari kiamat kamu tidak mengatakan: "Sesungguhnya kami (bani Adam) adalah orang-orang yang lengah terhadap ini (keesaan Tuhan)"

Berkaitan dengan world view yang membedakan Islam dengan dunia barat adalah fenomena yang terbentuk melalui kesengajaan yang berada dalam fikiran rasional dan penginderaan menolak adanya aspek lain yaitu Tuhan yang tidak bisa dirasio dan dilihat. Unity of God atau Tauhid adalah esensi dari peradaban Islam. Islam, budaya Islam, peradaban Islam mempunyai esensi pengetahuan yang dinamakan Tauhid. Tauhid memberikan peradaban Islam sebagai identitasnya yang mengikat semua komponen-komponennya bersama dan membuatnya menjadi satu bagian yang integral (Al Faruqi 1998:17). Menurut Al Faruqi (1998:1): 
"The God occupies the central position in every muslim place, every muslim action, every muslim thought. The presence of God Fills the muslim's consciousness at all times. With the muslim, God is indeed a sublime obsession."

Dalam fenomenologi ini, penulis menggunakan fenomenologi yang diekstensikan dengan konsep Tauhid yang dipaparkan oleh Al-Faruqi (1998). Menginternalisasikan nilai-nilai Tauhid kedalam setiap noema, noesis dan eidetic reduction serta menggunakan konsep Tauhid dari Al Faruqi (1998). Tahapan yang dilakukan adalah wawancara mendalam dengan informan, memaknai kesadaran informan dengan tatap muka langsung, menggunakan alat perekam dan juga menulis, menganalisa kesadaran yang muncul dalam diri informan mengenai kesengajaan terbentuknya fenomena, serta hakikat fenomena yang informan alami. Dalam tahapan analisis data, kami melakukan olah rasa/olah batin/hati guna menangkap dan memahami kesadaran atas fenomena yang dialami oleh informan serta menggunakan refleksifitas peneliti. Karena hati adalah sumber pengetahuan maka perlunya melakukan penyucian hati untuk mendapatkan kebenaran yang sesungguhnya.

\section{HASIL DAN PEMBAHASAN}

Manajemen Berbasis Kepentingan Organisasi vs Manajemen Berbasis Ibadah

Ketika kami bertanya terkait dengan cabang bisnis, abah menjawab begini:

"Banyak komplain ini kok begini, ini kok rasanya beda ini masaknya gimana, ini gimana ni bah pelayannya, saya kesana anaknya gak ada, tidur katanya, sampek dibangunin sama pembeli, saya kan malu ya akhirnya diringkes saja lah ya"

Adanya permasalahan-permasalahan yang muncul termasuk di dalamnya adalah kualitas makanan yang tidak sesuai serta karyawan yang tidak disiplin membuat Abah menutup cabang yang ada, seperti yang Abah paparkan berikut ini.

“...Sebetulnya tidak memberikan kontribusi besar, minimal bisa bayar tempat, minimal bisa kebayar gaji, saya udah bagus ya, karena tujuan saya bukan semata-mata cari untung saja saya ingin ibadah memenuhi orangorang yang membutuhkan lapangan pekerjaan, itu kan sudah bebas ya, eee Allah akan mengganti dengan bentuk lain..."

Dari ide atau pemikiran atau noesis apa yang disampaikan si Abah di atas bahwa adanya keikhlasan, kasih dan wujud syukur dari Abah, kepasrahan yang disandarkan kepada Allah SWT dan berpegang pada-Nya. Laba bukanlah tujuan utama dari bisnis bubur Abah, akan tetapi bisnis bubur ini merupakan sarana menuju kepadaNya. Keberaniannya mengungkapkan hal ini karena Abah melihat bahwa Allah selalu bersamanya, selalu menolongnya jika dia terjatuh. Berbeda dengan manajemen bisnis konvensional bahwa tujuan akhirnya adalah berorientasi pada kepentingan pemilik atau perusahaan (Choudury dan Harahap 2009; Mackay 2007; Porter dan Kramer 2011). Dengan alasan ini maka Abah juga melayani pelanggan dengan baik:

"Kalau misal kurang garam, dicicipi kalau ternyata iya, ya tambahi lah garam, apa susahnya kan positif ya"

Abah menjelaskan dengan sabar bahwa jika ada yang komplain jangan seperti pengalaman yang ia alami saat menjadi konsumen sebuah merk mobil ternama, karena merasa di pim-pong maka abah kecewa dengan pelayanan merk mobil tersebut.

"Memang tidak ada yang sempurna, tapi pelayanan komplain pada masyarakat harus diterima dengan baik, jangan dicuekin, di pim-pong"

\section{Keuntungan Sebesar-Besarnya vs Keun- tungan Lillahi Ta'ala}

Selanjutnya kami menanyakan soal laba yang dengan jumlah berapapun di dalam Islam sendiri tidak melarang adanya laba tersebut. Muncul tanggapan dari Abah sebagai berikut:

“ eee...Islam gak melarang ya, tidak memberi batasan, pokoknya saling menerima ya dan yakin produk kita bisa diterima dan wajar dikasih harga sekian rupiah. Kita bukan masalah harga, kare- 
na prosesnya juga, seperti bubur tidak seperti membuat nasi, klo bubur ini kan membutuhkan tenaga, perhatian jadi kalau wajar lah yak klo umpama harganya bisa satu kali lipat, atau berlipatlipat, tapi kalau berlipat-lipat kan seseorang ini rakus amat, itu yang tidak diperbolehkan oleh agama ya."

Konsep tidak adanya pelarangan laba oleh agama memang menjadi legitimasi tersendiri bagi bisnis-bisnis saat ini, akan tetapi jika laba atau keuntungan sebagai tujuan akhir, itu perlu dipertanyakan, apakah memang maqashid syariah adalah mencari keuntungan? Menurut Abah jika seperti itu maka seseorang menjadi rakus, dan itu tidak diperbolehkan agama. Abah menghindarkan dirinya dari kerakusan dengan mengikatkan dirinya pada moral dari agama, yang dianggap mampu mengendalikan nafsunya untuk meraup keuntungan yang tidak wajar. Lebih lanjut Abah memaparkan tentang keuntungan lain dalam berjualan bubur miliknya:

"Masalah waktu juga, sisi waktu, saya kan masak ini rutinitas saya kan jam 3 saya harus bangun, harus sudah kompor sudah standby, ayam, bubur sehingga cetrek-cetrek saya bisa melakukan aktivitas sholat sambil nunggu mateng, cakue kan 2 jam, jadi longgar, kalau bubur 5-10 menit saya harus tinggalkan, itu tadi prosesnya memerlukan perhatian. Nah jadi itu saya bisa sholat apalagi kalau bangunnya jam 2 setengah 3 , saya bisa sholat sebelum ke dapur"

Memasak bubur tidak mengganggu aktivitas ibadahnya kepada Allah SWT karena waktu yang ia gunakan untuk memasak bubur bisa juga digunakan untuk sholat Tahajjud ketika bangun pagi sebelum memasak bubur. Alasan semacam ini tidak terdapat dalam manajemen konvensional dalam melakukan aktivitas bisnis, karena tujuan awal yang melandasi bisnis adalah untuk mencari keuntungan, sehingga relijiusitas ditinggalkan begitu saja.

Hal ini jelas berbeda dengan manajemen konvensional, yang tujuannya adalah tujuan organisasi dan untuk kepentingan manajer. Bahkan pembelaan yang diungkapkan oleh Mackay (2007) pun berujung pada kepentingan pemilik modal.
Abah dahulunya merupakan seorang pekerja swasta yang pangkatnya sudah sangat tinggi, sudah bertahun-tahun beliau menjalani profesinya, ada fasilitas mobil, rumah dan juga gaji yang hitungannya sudah sangat diatas rata-rata, lalu selanjutnya kenapa berani melepaskan kemapanan tersebut, berikut jawaban dari Abah.

"Lha itu ...itu membutuhkan keberanian... karena Allah aja ya karena Lillahi ta'ala.. karena Allah saya harus menjalani hidup lebih baik, itu aja kuncinya kok berani meninggalkan fasilitas yang sudah saya miliki."

Lillahi Ta'ala.. apa yang disebutkan oleh Abah merupakan kesadaran bahwa semua aktivitas harus didasarkan oleh Allah saja, inilah prinsip ketauhidan, dimana Tauhid harus melandasi setiap aksi setiap Muslim (Al Faruqi 1998:1). "Lillahi Ta'ala" merupakan kesadaran transendental dari Abah, tanpa berfikir apapun mengenai itu, ucapan itu langsung muncul secara spontanitas, ini menunjukkkan bahwa "Lillahi Ta'ala" merupakan sebuah kebiasaan yang sudah dilakukan Abah dalam jangka waktu yang lama sehingga menjadi satu kesadaran yang melekat dalam diri Abah. Lebih lanjut Abah mengatakan:

"Kan sempat memang ditentang sama keluarga, dan di masyarakat itu menjadi tidak umum ya, kan sudah mapan secara dunia gitu ya, secara dhohir (dunia), kok ditinggalkan, lha mereka gak tahu ada sisi yang gak bener gitu lho, yang dicontohkan sama Rosulullah, ini yang membuat saya ingin keluar."

Keberanian ini merupakan sebuah contoh keputusan yang bertentangan dengan bisnis kebanyakan yang ada sekarang ini. Muncul sisi kesadaran bahwa apa yang dilakukan selama ini (sebelum menjalani profesinya sebagai seorang penjual bubur) adalah sesuatu hal yang salah. Bahwa "dhohir" itu tidak benar, kemapanan itu harus ditinggalkan karena muncul kesadaran adanya ketidakpuasan tentang yang dhohir itu tadi, muncullah konsep spiritual yang ada di dalam diri Abah yaitu seperti apa yang dicontohkan oleh Rasulullah SAW, Rasulullah SAW sendiri dikenal sebagai seorang Rasul yang membawa kebenaran wahyu Allah, 
artinya disini melekat sekali dalam kesadaran Abah untuk meneladani Rasulullah SAW yang selalu membawa kebenaran dari Allah SWT.

Jika sudah bergantung pada Allah semata, maka kekhawatiran akan mundurnya sebuah usaha akan berkurang, karena istiqomah menjadi kunci utama, dan penentu segalanya adalah Allah semata, seperti inilah ungkapan Abah ketika ditanya mengenai kekhawatiran tersebut.

"Sebagai manusia biasa ada, saya gak munafik, tapi kadarnya kecil, saya lebih yakin pada kebesaran Allah aja ya. Selama kita jujur melakukan kewajiban-kewajiban kita, kalau ada yang mulai menurun seperti omset, saya cari sendiri, tapi saya dulu-dulu itu sebelum saya melakukan aktivitas-aktivitas lain, dirumah sudah sholat malam, do'a, baca Qur'an, saya biasanya baca Qur'an, kalau menjelang dhuha ya sholat dhuha dulu lalu baca Qur'an. Kalau aktivitas saya kendor, saya gak terasa mbak mungkin Allah memperingatkan saya"

Hubungan antara dunia dan akhirat tidak terlepas sama sekali dalam kegiatan bisnis Abah yang dilambangkan dengan omset yang didapat oleh Abah. Abah menganggap jika omsetnya menurun maka itu merupakan peringatan dari Allah SWT untuk mengingatkannya agar lebih mendekat kepada-Nya.

\section{Menghidupi Secara Material vs Menghidu- pi Secara Spiritual}

Kehidupan dhohir yang dialami Abah sebelum menjalani profesinya sebagai seorang penjual bubur merupakan sebuah kehidupan yang belum menghidupi, dalam arti aspek spiritual. Berikut ini penelusuran penulis ketika bertanya mengenai kehidupan yang menghidupi. Apakah cabang-cabang termasuk rombongnya juga kepunyaan Abah, jadi cuma mempekerjakan karyawan disitu? Lalu Abah menjawab begini:

"Iya, mempekerjakan karyawan dan menempatkan karyawan saja, kan saya memberikan lapangan pekerjaan ya"

Sebagai seorang leader, Abah ini memberikan kehidupan secara spiritual kepada karyawannya, tidak mementingkan ego atau self saja, karena hubungan antara pemilik/ manajer dengan karyawan disini sudah tereduksi, jika hal yang diatas merupakan noema yang diungkapkan oleh Abah, berikut merupakan pengakuan dari Abah mengenai hubungannya dengan karyawan dalam menangani masalah komplain dengan karyawan.

"Saya tahu, saya berdosa ya kalau menzholimi karyawan ya, istirahat aja saya suruh istirahat, sholat aja saya suruh sholat, kan tanggung jawab saya, itu kok juragannya sholat dan ngaji, tapi karyawannya gak boleh kan dosa, gak barokah saya ini ya"

Dari apa yang dipaparkan oleh Abah di atas, terlihat sebagai seorang pemimpin abah memperlakukan karyawannya dengan adil dan bijaksana terutama kebebasan dalam beribadah kepada Allah SWT. Alasannya adalah adanya kesadaran dari Abah tentang adanya hari akhir yang pada saatnya nanti akan dimintai pertanggungjawaban atas apa yang sudah ia lakukan.

"Lha ini dimintai pertanggungjawaban sama Allah, sudah kau apakan hai Ate' karyawanmu itu? Kenapa gak disuruh sholat, kenapa gak disuruh ngaji, termasuk istirahat, silahkan anda istirahat silahkan anda sholat, ya istirahat lah di masjid, leyeh-leyeh lah silahkan kalau masih ada waktu. Tapi ya tau waktu lah ya, masak dua jam baru masuk ikut leyehleyehan, ya saya suka guyon lah ya sama anak-anak, saya bilang anda adalah anak saya jadi kalau salah ya saya marahin."

Jadi pernyataan Abah di atas merupakan manifestasi dari hubungan kasih sayang yang dimetaforakan sebagai seorang ayah yang sedang mendidik anak-anaknya dengan penuh perhatian dan rasa tanggung jawab yang tinggi dan selalu memberikan pencerahan.

Sedangkan perlakuan Abah sebagai seorang ayah terlihat dengan perhatian-perhatian yang diberikan Abah pada karyawan-karyawannya.

“...Walaupun sekarang bukan saya yang mengerjakan, ada SOP- 
nya, karyawan bangun saya ikut bangun, itu tadi, saya bisa sholat ya, anak-anak saya anjurkan, sholat dulu, dengan bangun lebih awal, saya beri keleluasaan, dhuha juga saya tulis, sudahkah anda solat dhuha? Nanti menjelang subuh "Allahu Akbar-Allahu akbar" (suara Abah menirukan orang adzan) tinggalkan dulu (memasak bubur) lalu pergi ke masjid. Nah, jadi dari sisi waktu saya milih yang dari segi ibadahnya bisa."

Abah memperlakukan karyawannya dengan penuh rasa kasih sayang, karena sayang sebagai seorang ayah seperti yang disebutkan diatas, maka ia mengingatkan untuk selalu sholat, selalu memperhatikan karyawannya. Keseimbangan kesejahteraan antara Abah dan karyawannya dalam hal kehidupan spiritual menunjukkan perbedaan tujuan dalam manajemen konvensional yang dipaparkan oleh Taylor (1911/2004) bahwa seolah-olah pekerja harus sejahtera, karena kesejahteraan karyawan sendiri merupakan penentu utama kesejahteraan pemilik usaha yang mempekerjakan mereka, hak untuk mendapat kesejahteraan total sebagai manusia yang utuh pun musnah dalam prinsip manajemen yang dipaparkan oleh Taylor (198/2004):

"The principle object of management should be to secure the maximum prosperity for the employer, coupled with the maximum prosperity for each employee. The words "maximum prosperity" are used, in their broad sense, to mean not only large dividends for the company or owner, but the development of every branch of the business to its highest state of excellence, so that the prosperity may be permanent. In the same way maximum prosperity for each employee means not only higher wages than are usually received by men of his class, but, of more importance still, it also means the development of each man to his state of maximum efficiency"

Mekanisme Pengendalian Berbasis Insentif vs Mekanisme Pengendalian Berbasis Lillahi Ta'ala

Dalam manajemen bisnis tidak bisa lepas dari pengawasan terhadap kar- yawannya dan operasionalnya, Abah juga memiliki mekanisme pengawasan untuk karyawannya.

"Klo dalam sistem yang sudah profesional kan berbagai cara, atau kalau nggak kan kita mampu membayar gaji karyawan, manajer lah, sehingga gak perlu ngontrol (yang dimaksud tidak perlu mengontrol langsung adalah pemilik usaha)"

Abah menyadari bahwa mekanisme pengawasan adalah hal yang sangat penting dalam menjalankan bisnisnya terutama manajer, akan tetapi Abah tidak memiliki manajer yang bertanggungjawab atas tugas pengawasan tersebut. Sistem saat ini sudah sangat canggih untuk mempermudah pengawasan yang ada dalam proses manajemen saat ini, seperti misalnya ada CCTV dan manajer yang di setiap cabang sebuah bisnis yang pasti mempunyai peranan penting juga insentif yang diberikan karyawan. Akan tetapi dalam manajemen bisnis Abah saat ini, Abah tidak menggunakan sistem-sistem canggih tersebut, akan tetapi menggunakan sistem alami sebagai berikut:

"Klo Abah kembali yak manajemen Lillahi ta'ala ya hehe, kuncinya apa... satu, kan abah jarang ngontrol, abah disini seharian ya, memang penting agar gak terjadi loosing ya, kebocoran atau kehilangan, pakai bon, pake hitungan manusia, bon yg masuk dicocokkan, kalau ada ketimpangan ya dicocokkan ya, dua pake register, jadi bon register uang harus seimbang. Lalu dalam menerima karyawan, ada tiga faktor, satu, yang mngerjakan sholat, dua tidak merokok, tiga mau mengikuti pengajian, saya yakin walaupun saya tidak sholat, saya lebih seneng punya karyawan yang rajin sholat ya pasti amanah. Percuma pinter, tapi akhlak tidak bagus, pasti ada takutnya kalau orang sholat. Takut, selalu berhati-hati, karena anak-anak sudah saya beritahu seperti itu, insya Allah mudah-mudahan takut untuk melakukan yang tidak-tidak, saya slalu ingatkan "ingat lho ya dipundakmu ada malaikat. Karena saya 
menggunakan manajemen Lillahi ta'ala, saya yakin anak-anak itu kecil sekali mau melakukannya (maksudnya disini melakukan kecurangan)."

Tidak seperti dalam manajemen konvensional, mekanisme pengawasan yang berbasis insentif mengasumsikan manusia sebagai homo economicus semata, menginginkan uang semata. Akan tetapi apa yang ditunjukkan Abah, bahwa manajemen Lillahi Ta'ala ini merupakan pengungkapan secara tidak langsung bahwa manusia merupakan homo religious, selalu mengenal Allah di dalam dirinya, bukan sebagai mesin, mereka mempunyai hati, merasakan dan berfikir dan Allah mengawasi langsung dari setiap kegiatan yang dilakukan oleh anakanak (karyawan Abah).

Pengawasan Lillahi ta'ala tidak hanya Abah terapkan dalam mekanisme pengawasan karyawannya saja, akan tetapi juga pengawasan terhadap rekan kerja, atau franchise yang dijual kepada orang lain mengingat lokasi franchise tersebut ada di luar kota, berikut jawaban Abah ketika kami tanya mengenai ada tidaknya ketakutan jika ayam yang digunakan dalam membuat bubur tidak syariah:
"Ya sudah komitmen, di luar itu wallahu'alambissawab..."

Kepercayaan terhadap mitra karena keyakinan kepada Allah Ta'ala:

"Saya nggak bisa ngontrol terus, ya jadi tanggung jawab dia ya, ya Lillahi ta'ala mau masuk surga atau neraka, gitu aja"

\section{Skema Bisnis yang "Menghidupi"}

Berdasarkan hasil penelitian diatas bahwa skema bisnis yang kami gagas berdasarkan pada landasan spiritual yang muncul dalam praktek yang ada saat ini. Rasa keikhlasan, kasih sayang, dan manajemen Llillahi Ta'ala yang terungkap diatas akan menjadi unsur-unsur penting dalam kegiatan bisnis yang ada. Berlandaskan dengan Tauhid sebagai esensi dan identitas dari Islam memancarkan cahaya spiritualitas, kasih sayang, ikhlas, moral dan Lillahi Ta'ala yang tergabung dalam satu dimensi spiritual mentransferkan nilai-nilai spiritual yang ada didalamnya sehingga masuk kedalam dimensi praktek dengan menciptakan kepemimpinan yang adil, komunikasi atau shura, lingkungan bisnis Islami dan motivasi yang bersifat spiritual untuk kebahagiaan akhirat yang semuanya terikat dalam satu kesatuan dan bersifat resiprokal.

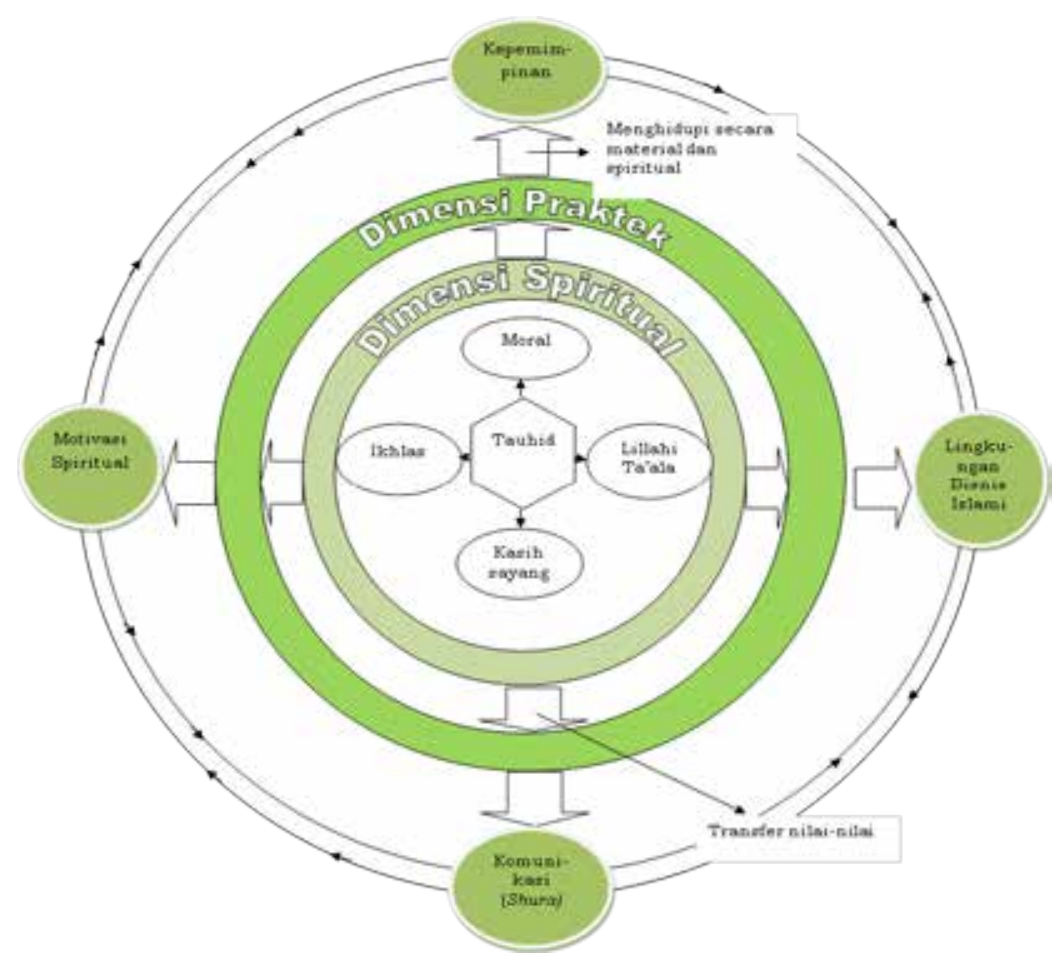

Gambar 1. Mind Mapping Penelitian 


\section{SIMPULAN}

Landasan yang berbeda dalam manajemen bisnis konvensional yang merupakan turunan dari scientific management serta perbedaan pandangan dalam Islam serta yang melandasinya menyebabkan perbedaan yang sangat mencolok dalam manajemen bisnis konvensional dengan manajemen bisnis syariah. Manajemen bisnis konvensional berlandaskan pada kepentingan pemilik atau manajer yang ada di perusahaan, sedangkan manajemen bisnis Islami berada dalam payung syariah dengan tujuan utama membawa keadilan dan kemakmuran umat yang merupakan tugas dari manusia itu sendiri sebagai khalifah di muka bumi.

Manajemen bisnis Islami mendasarkan kegiatannya pada ketaatan, istiqomah, keikhlasan yang disandarkan pada Allah semata sehingga memunculkan manajemen bisnis Lillahi Ta'ala dengan Tauhid sebagai landasan atau pijakan utamanya, sehingga mampu membuka jalan menuju pembebasan ekonomi Islam yang masih terkurung dalam bayang-bayang ekonomi kapitalis. Disamping itu, diharapkan dari penelitian ini dapat memberikan bentuk manajemen bisnis Islami sebagai kehidupan yang menghidupi dalam artian menghidupi secara material dan juga kehidupan spiritual. Penelitian ini hanya terbatas pada isu-isu tertentu saja, maka penelitian ini memberikan peluang yang sangat luas dalam bidang manajemen bisnis Islami lainnya yaitu manajemen keuangan Islami.

\section{DAFTAR RUJUKAN}

Abbasi, A.S, Rehman, K.U dan Bibi. A. 2010. Islamic Management Model. African Journal of Business management. Vol. 4 No. 9, hlm 1873-1882.

Alani, Farooq; Yaacob, Hisham dan Hamdan, Mahani. 2013. The Comparison of Financial Analysis Tools in Conventional and Islamic Banking: Evidence From Kuwait. International Journal of Business and Management. Vol. 8 No. 4, hlm 85-103.

Al Attas, Syed Muhammad Naquib. 2001. Prolegomena To The Metaphysics of Islam. International Institute of Islamic Thought And Civilization (ISTAC). Kuala Lumpur.

Al Faruqi, Ismail Raji. 1998. Al Tawhid: Its Implications For Thought and Life. The International Institute of Islamic Thought. Virginia.
Alvesson, Mats dan Willmott, Hugh. 2007. Making Sense of Management: A Critical Introduction. Sage Publication. UK.

Ather, S.M, Khan, M.A dan Hoque, N. 2011. Motivation as Conseptualised in Traditional and Islamic Management. $\mathrm{Hu}$ maneconomics, Vol. 27 No. 2, hlm 121137.

Branine, M dan Pollard, D. 2010. Human Resource Management With Islamic Management Principles A dialectic For A Reverse Diffusion In Management. Personal Review. Vol. 39 No. 6, pp 712727.

Burrell, G. and G. Morgan. 1979. Sociological Paradigms and Organisational Analysis: Elements of the Sociology of Corporate Life. London: Heinemann.

Chiapello, E. 2007. Accounting and the birth of the notion of capitalism. Critical Perspective on Accounting. Vol. 18, hlm 263-296.

Choudhury, M.A dan Harahap, S. S. 2009. "Complementing Community, Busniness and Microenterprise by The Islamic Epistemological Methodlogy." International Journal of Finance and Middle Eastern Finance and Management. Vol. 2 No. 2, hlm 139-159.

Dewi, A. C. E dan Dhewanto, W. 2012. Key Succes Factor of Islamic Family Business. Procedia-Social and Behavioral Science. Vol. 57, hlm 53-60.

Fontaine, Rodrigue. 2008. Problem Solving: An Islamic Management Approach. Cross Cultural Management: An International Journal. Vol. 15 No. 3, hlm 264274

Fontaine, R, Oziev, G dan Hassan-Hussein, H. 2012. Evaluating Chris Argyris's Ideas: An Islamic Perspective. Journal Of Management Development. Vol. 31 No. 10, hlm 1046-1057.

Khan, B; Farooq, A dan Hussain, Z. 2010. Human Resource Mangement: An Islamic Perspective. Asia Pasific Journal of Business Administration. Vol. 3 No. 1, hlm 17-34.

Kuswarno, Engkus. 2009. Metode Penelitian Komunikasi Fenomenologi Konsepsi, Pedoman dan Contoh Penelitiannya. Widya Padjajaran.

Mackay, John. 2007. Be the Solution How Entrepreneurs and Concious Capitalists Can Solve All The World's Problems (edited by Michael Strong). John Wiley and Sons Inc. New Jersey. 
Mas'ud, Fuad. 2008. Menggugat Manajemen Barat. Badan Penerbit UNDIP. Semarang.

Mohiuddin, M.G. 2012. Management Views in Islamic Literature: A Conceptual Analysis on The Way of New management Dimension. International Journal of Management. Vol. 3 No. 2, hlm 411424.

Noruzi, Mohammad Reza. 2011. A Quick Look on Islamic Entrepreneurship. Interdisplinary Journal of Contemporary Research in Business, Vol. 2 No. 10, hlm 478-484.

Porter, Michael E dan Kramer, Mark R. 2011. Creating Shared Value How To Reinvent Capitalism-and Unleash a Wave of Innovation and Growth. Hardvard Business review, hlm 1-17.

Rice, Gillian. 1999. Islamic Ethics and The Implication for Business. Journal of Business Ethics. Vol. 18 No. 4, hlm 345-358.

Rizk, R. R. 2008. Back to Basics: An Islamic Perspective On Business and Work Ethics. Social Responsibility Journal. Vol. 4 No. 1, hlm 246-254.
Shihab, M. Quraish. 1996. Wawasan AlQur'an: Tafsir maudhu'i atas Pelbagai Persoalan Umat. Band. Mizan.

Sombart, W. A. 1911(2001). Jews and Modern Capitalist (diterjemahkan oleh M. Epstein. Batoche Books. Kitchene.

Tayeb, Monir. 1997. Islamic Revival in Asia and Human Resource Management. Employe Relation. Vol. 19 No. 4, hlm 352-364.

Taylor, Fredrick Winslow. 1911(2004). The Principle Of Scientific Management. Project Guttenberg File.

Wren, Daniel A dan Bedeian, Arthur G. 2009. The Evolution of Management Thought. John Wiley \& Sons, Inc. US.

Zangoueinezhad, Abouzar dan Moshabaki, Ashgar. 2011. Human Resource Management Based on The Index of Islamic Human Development The Holy Quran's Approach. International Journal of Social Economics. Vol.38 No. 12, hlm 962972. 


\begin{tabular}{|c|c|c|c|}
\hline \multicolumn{2}{|c|}{ 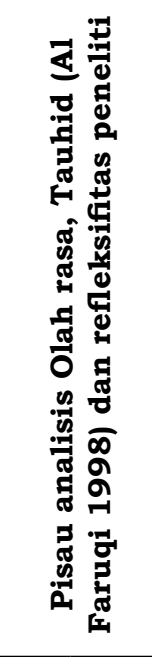 } & 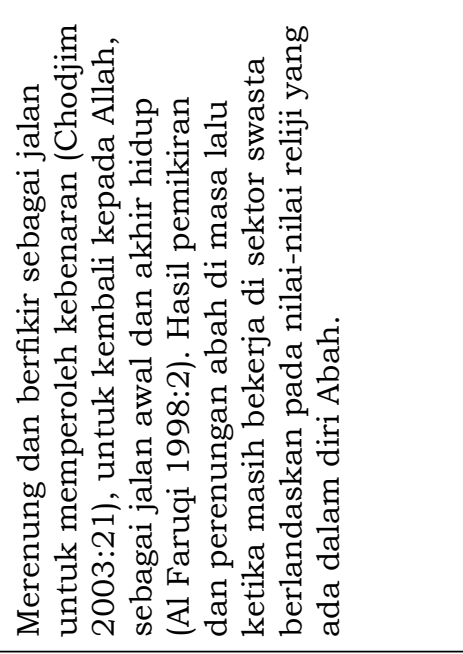 & 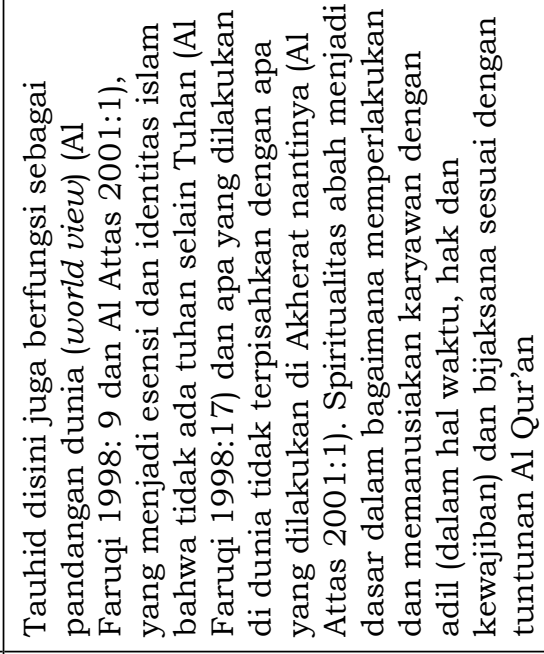 \\
\hline \multicolumn{2}{|r|}{ 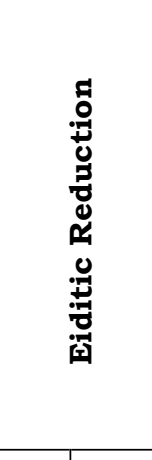 } & 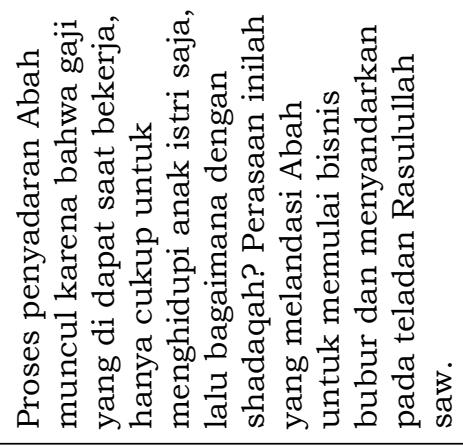 & 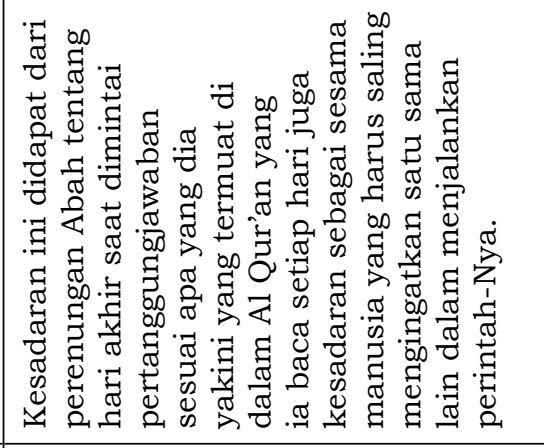 \\
\hline \multirow{2}{*}{ 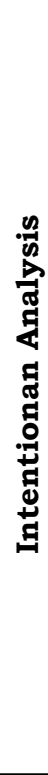 } & $\begin{array}{l}\frac{n}{5} \\
0 \\
0 \\
0\end{array}$ & 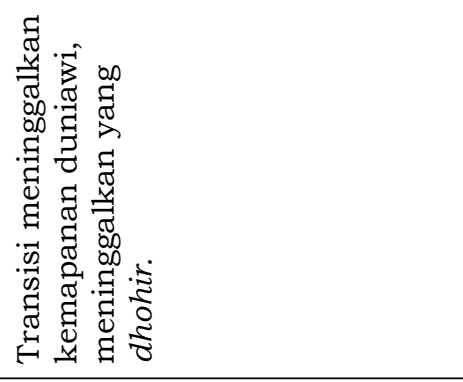 & 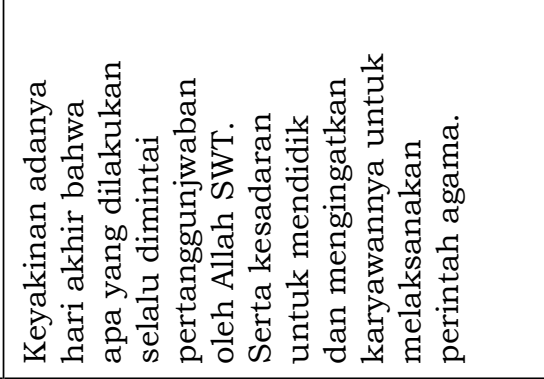 \\
\hline & 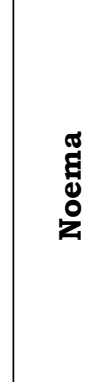 & 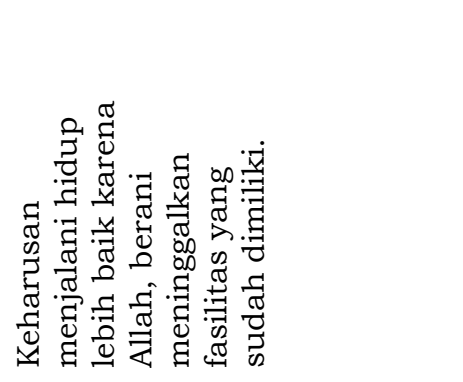 & 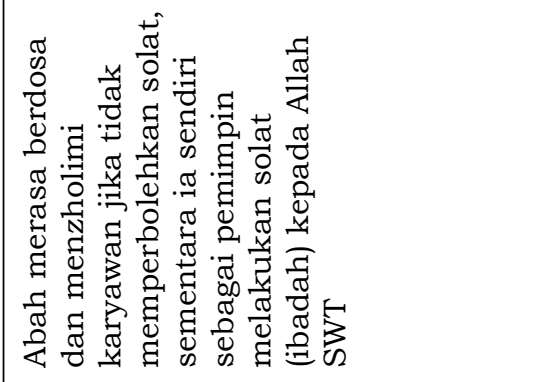 \\
\hline \multicolumn{2}{|c|}{ 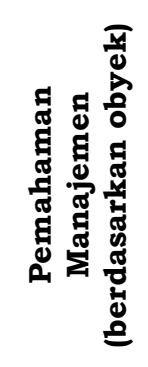 } & 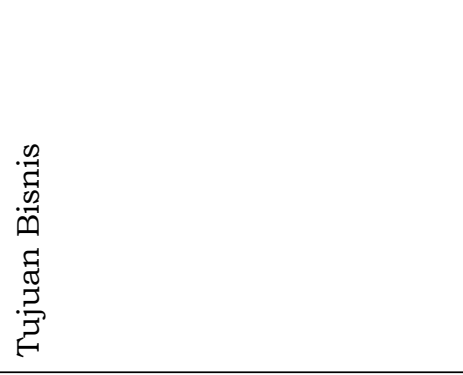 & 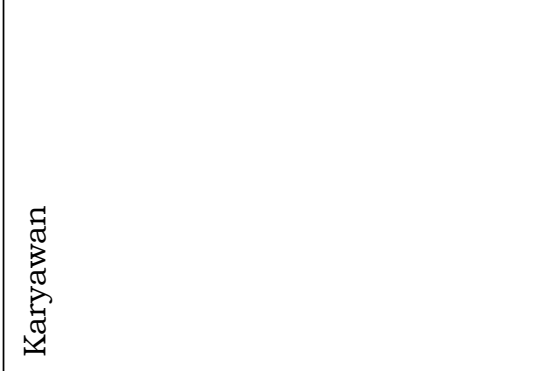 \\
\hline \multicolumn{2}{|r|}{$\stackrel{0}{\mathbf{Z}}$} & $\dot{-}$ & $\dot{\sim}$ \\
\hline
\end{tabular}




\begin{tabular}{|c|c|}
\hline 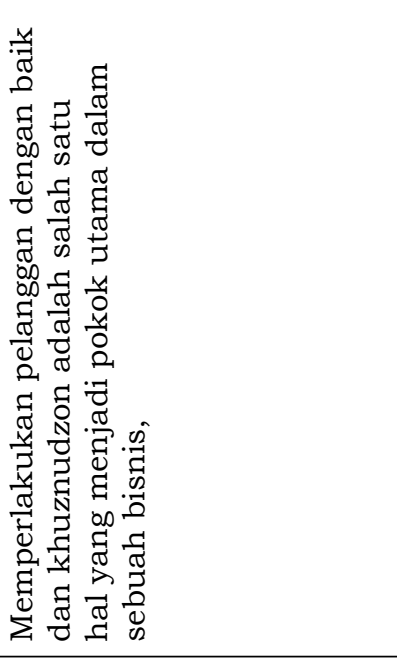 & 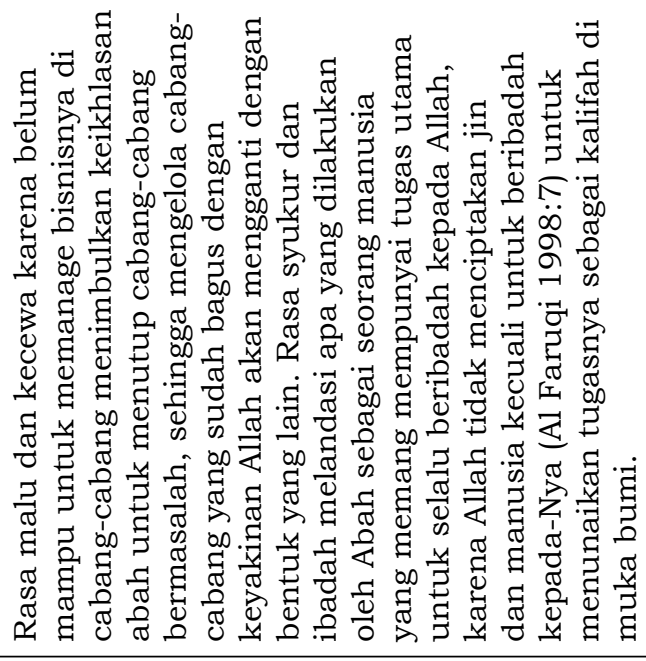 \\
\hline 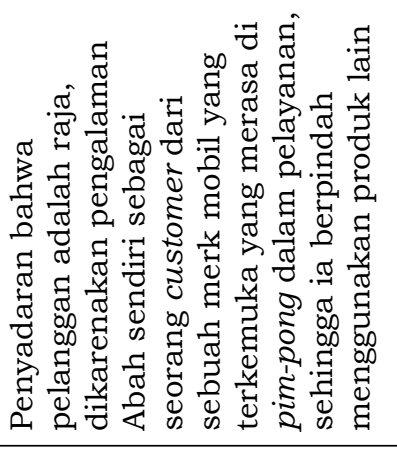 & 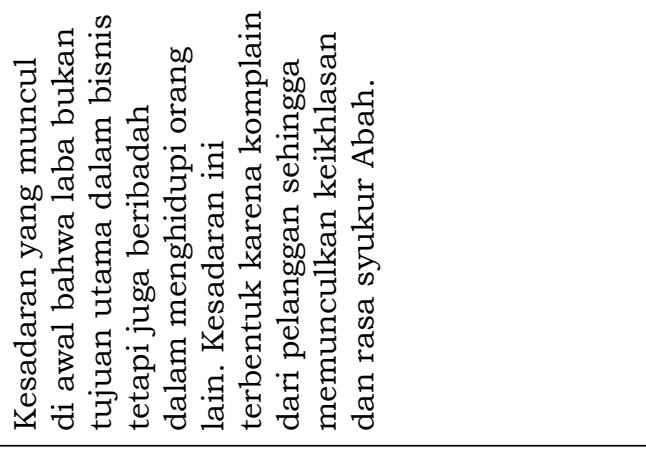 \\
\hline 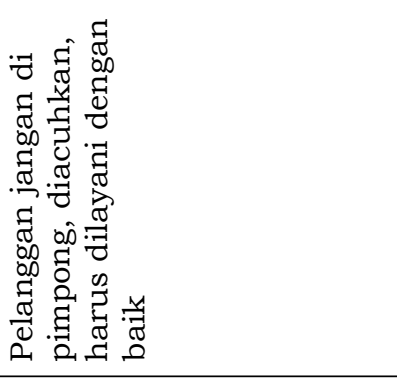 & 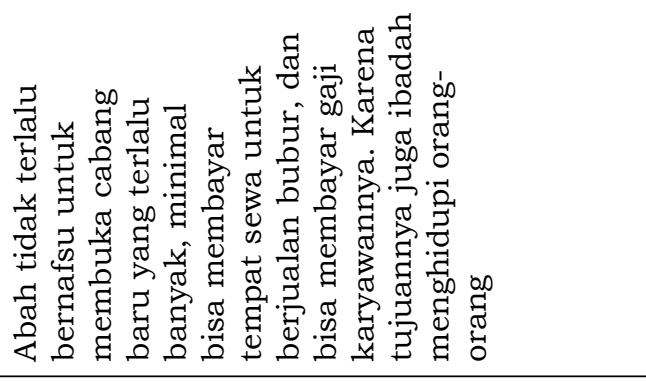 \\
\hline 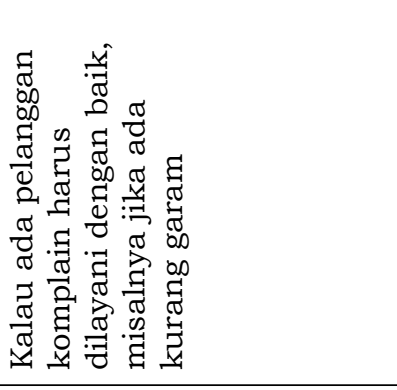 & 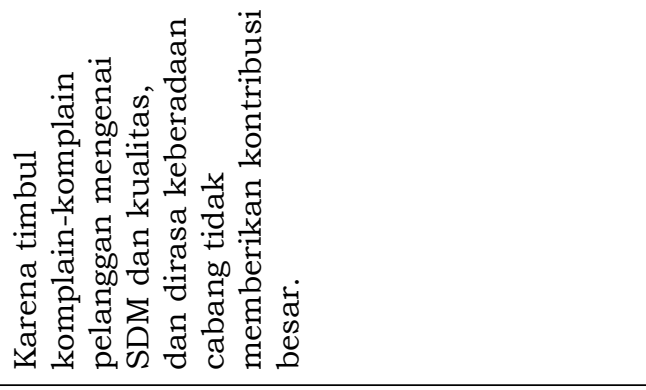 \\
\hline & 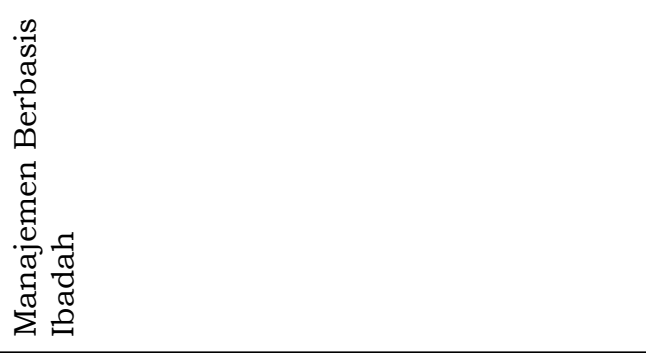 \\
\hline$\dot{m}$ & ஓ் \\
\hline
\end{tabular}




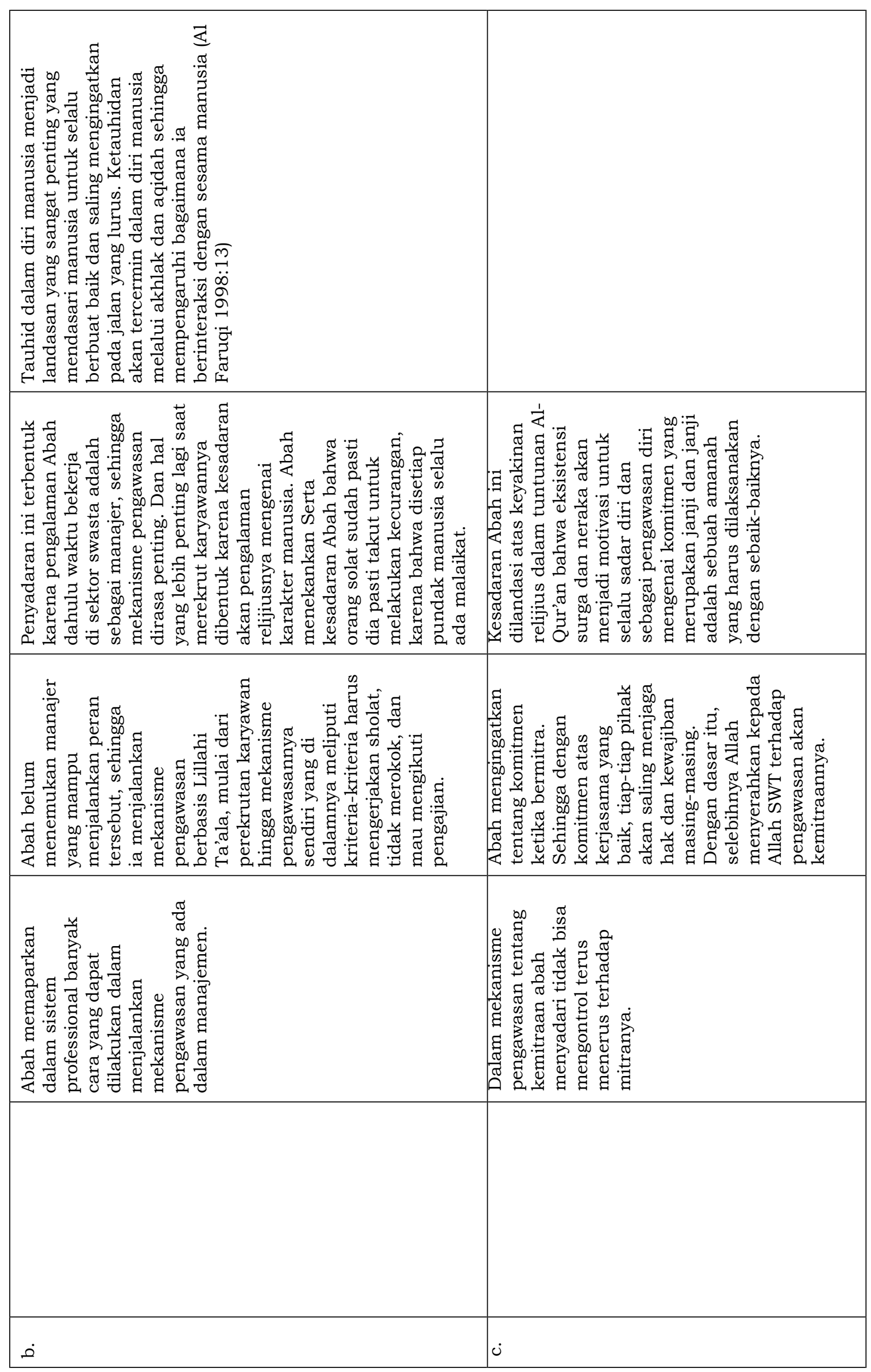

